\title{
三次元脳磁界計測に基づく特異値分解を用いた複数信号源推定の検討
}

\author{
正 員 小林宏一郎 (東京電機大学超電導応用研究所) \\ 正 員 内川 義則 (東京電機大学理工学部)
}

\section{Multiple source estimation using singular value decomposition on a three dimensional measurement of magnetoencephalogram}

\author{
Koichiro Kobayashi, Member (Tokyo Denki University) \\ Yoshinori Uchikawa, Member (Tokyo Denki University)
}

\begin{abstract}
This paper describes a computer simulation study for estimating the multiple sources in the brain based on a three dimensional measurcment of magnetoencephalogram (MEG). We proposed a new method of estimation algorithm using spatio-temporal data of MEG and singular value decomposition analysis. The number of estimation source is decided by number of dominant singular value of spatio-temporal MEG data. The source localization is done as pattern matching by signal subspace of singular vectors and projection of an estimating source.

The results show estimation errors with the phase difference and the distance of two dipole sources. This proposed method can estimate two sources, which are more than $2 \mathrm{~cm}$ apart and 15 degree phase difference. We conclude this method is useful as multiple source estimation.
\end{abstract}

キーワード；時間・空間デー夕，特異值分解，複数信号源推定，三次元磁界計測

\section{1.はじめに}

近年, SQUD 磁束計を用いた脳磁界計測が盛んに行わ れるようになった。この脳磁界計測は，生体の活動に伴う 微茨な磁界を計測することが可能であるため，医療などへ の応用が期待されている。しかし, 計测磁界から脳内の信 号源を推定する手法が確立されておらず，重要な課題の一 つとなっている。

代表的ないくつかの方法として，(1)信号源を 1 つの電流 双極子と仮定する等価電流双極子 (ECD) 法(1)，(2)，(2)離散 化した信号源空間に対し信号源の数や強度をしらみつぶし に探索する方法(3)，(3)離散化した信号源空間に対し単位信 号源の分布を求める方法(4)，(4)時系列信号の相関行列を分 析し信号源の数や自由度を求め推定する方法(5),(6)など様々 な方法が提案されている。しかし，測定面から樑い信号源 が存在する場合，信号源間の相関が強い場合，複数の電流 双極子が近接して存在する場合，雑音が大きい場合などの 条件下では，推定が困難となる(3),(5),(7)。そこで, 本研究で は, 斎藤らが提案した SPM 法(4),(8)(上記(3))とJ.C.Mosher らが提案した MUSIC 法(5)（上記(4)）を応用した推定方法 の提案を行った。SPM 法は, 信号源の大きさを単位值に限 定し単位信号源が測定部位に与える磁界の空間分布と, 測 定された即知磁界分布の一致度合いを Cauchy-Schwarz の関係式で求め, 信号源の大きさは単位信号源の空間的集
中度合いで推定する方法である。MUSIC 法は，時間・空 間デー夕を利用した相関行列の特異値分解を行い，信号部 分空間を抽出して，ノイズ部分空間との直交性より信号源 の存在を求める方法である。本提案方法では, MUSIC 法 の相関行列の特異值分解より信号部分空間を抽出すること により，時間・空間情報の利用およびノイズ除去を行い， SPM 法の単位信号源の空間分布を Cauchy-Schwarz の関 係式（本提案方法における信号部分空間への射影）で求め ることにより，直交性を持たない複数信号源を推定する。 しかし，この方法も他の推定方法と同様に解を一意的に求 めることはできない。また本提案方法は，離散化した信号 源空間における信号源の存在を求める方法でなく，信号源 を電流双極子と仮定して，初期值を与えそれを逐次移動さ せることにより推定を行う。これは，三次元磁界計測にお ける接線成分が信号源直上で極值を持ち，信号源の位置の 情報を提供する特徽を利用した方法である(9)。

本研究では，磁界デー夕の時空間情報を利用して，複数 信号源の作る磁界の特異值分解を用いて個々の信号源とし て推定する方法を提案した。また，三次元磁界検出コイル を用いた脳磁界計測(7)想定したシミュレーションを行い， その有效性について検討を行った。

\section{2. 方法}


<2.1> 信年源モデルとその表現＼cjkstart信号源モデルは， 人体頭部を半径 $10 \mathrm{~cm}$ の均質導体球と仮定し, 測定点はモ デル表面に沿った $2 \mathrm{~cm}$ 間隔 $9 \times 9$ の計 81 点とした。座標系 は極座標系を用い, 半径方向を法線磁界成分 $\mathrm{Br}$, 頭頂から 耳に向かう方向を接線磁界成分 $\mathrm{B} \theta$, 鼻から左耳に向かう方 向を接線磁界成分 $\mathrm{B} \phi$ とした。三次元磁界計測において，接 線磁界成分は信号源の帰還電流である分布電流の影響を受 ける(10)。そのため磁界計算は，分布電流の影響も考庶し， Geselowitz の提案式(11)を用い，実際に著者らか使用してい る二次勾配型三次元磁界検出コイルの形状（法線磁界検出 用 : $28 \mathrm{~mm} \times 28 \mathrm{~mm}$, ベースライン $29 \mathrm{~mm}$ 接線磁界検出 用: $28 \mathrm{~mm} \times 58 \mathrm{~mm}$, ベースライン $14 \mathrm{~mm}$ )を基に行った。 また，磁界計测はサンプリング周波数 $2 \mathrm{kHz}$ で行い，解析 区間を $100 \mathrm{msec}$ とした。

ここで, I 個の電流双極子が存在する信昂源モデルを考

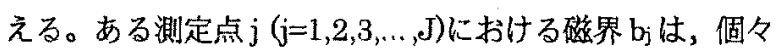
の双極子による磁界 $b_{i}(i=1,2,3, \ldots, I)$ 和として次のように 表わすことができる。

$$
b_{j}=\sum_{j=1}^{1} b_{j}
$$

次に電流双極子の時間変化を考虑したモデルについて考 える。各電流双極子の時系列信号は線形独立であるとする と，サンプリング時間 $\mathrm{k}(\mathrm{k}=1,2,3, \ldots, \mathrm{K})$ 中に得られる磁界 は，各時間のベクトルの集合として以下のように表せる。 但し，電流双極子の数と位置は不変であると仮定する。

$$
\mathrm{B}=\left[\begin{array}{cccc}
\mathbf{b}_{11} & \mathbf{b}_{12} & \cdots & \mathbf{b}_{1 \mathrm{~K}} \\
\mathbf{b}_{21} & \mathbf{b}_{22} & \cdots & \mathbf{b}_{2 \mathrm{~K}} \\
\vdots & \vdots & \ddots & \vdots \\
\mathrm{b}_{\mathrm{J1}} & \mathbf{b}_{\mathrm{J} 2} & \cdots & \mathbf{b}_{\mathrm{JK}}
\end{array}\right]
$$

この計測磁界 Bにおいて，J個の測定点で得られる磁界 データは,I個のベクトルの1次結合と見ることができる。 すなわち，全サンプリング時刻に捛ける磁界ベクトルの集 合 $B$ は,J次元空間内のI次元部分空間に完全に含まれる。 そこで，次に示す方法でこのI 次元部分空間を求め，この 部分空間とのパターンマッチングにより信号源推定を行う。

<2.2> 信号源推定法 式(2)に示した $J \times K$ 行列 B 奶して, 特異值分解を行う。行列 B D特異值分解は次の形 で表される。

$$
\mathrm{B}=\mathrm{U} \Omega \mathbf{V}^{\mathrm{T}}
$$

$\mathrm{U}$ の各列 $\mathrm{u}$ は $\mathrm{BB}^{\mathrm{T}}$ の非零固有值に対応した固有ベクトル， $\mathrm{V}$ の各列 $\mathrm{v}$ は $\mathrm{B}^{\mathrm{T}} \mathrm{B}$ の非零固有值に対応した固有べクトルで あり, $\mathrm{U}, \mathrm{V}$ を以後特異ベクトルと呼ふ。 $\Omega$ は $\mathrm{BB}$ \% の非䇰固 有值入により次のように表される。

$$
\Omega=\operatorname{diag}\left(\sqrt{\lambda_{1}}, \sqrt{\lambda_{2}}, \cdots, \sqrt{\lambda_{1}}\right)
$$

この $\Omega$ を磁界デー夕 B の特異值と呼ぶ。この非零特暴值
に対応する特異ベクトル集合U及びVで張られるI次元空 間が信号部分空間となる。U は磁界データ B の行ベクトル に対応し測定点情報を表し、Vは磁界データ Bの列ベクト ルに対応し時間情報を表す。ここで，I 個の信号源による 磁界が信号部分空間 U に含まれるように電流双極子のパ ラメータを決定する。そこで，I 個の信号源による磁界と 信号部分空間 U との整合性を以下の考え方により評価す る。ある 1 つの電流双極子により得られる磁界デー夕を $\mathrm{e}_{\mathrm{e}}=\left(\mathrm{e}_{1}, \boldsymbol{e}_{2}, \mathrm{e}_{3}, \ldots, \mathrm{eJ}\right)^{\mathrm{T}}$, 信号部分空間 U の各列べクトル(特異 ベクトル)を $\mathrm{u}_{i}(\mathrm{i}=1,2,3, \ldots, \mathrm{I})$ とすると, el から $\mathrm{u}_{\mathrm{i}}$ への射影係 数をUの各列べクトルについて求め, その係数を係数べク トル $\mathrm{pl}$ として表すと

$$
p_{1}=\left(\frac{u_{1}^{T} e_{1}}{u_{1}^{T} u_{1}^{T}}, \frac{u_{2}^{T} e_{1}}{u_{2}^{T} u_{2}^{T}}, \cdots, \frac{\mathbf{u}_{1}^{\mathrm{T}} e_{1}}{u_{1}^{T} u_{1}^{T}}\right)^{\mathrm{T}}
$$

となり，Uplは電流双極子の信号部分空間への射影となる。 この U pl と磁界データベクトル el $_{\text {とのマッチングを以下の }}$ 評価関数 $\mathrm{f}$ により俨䛧する。

$$
\mathbf{f}=\left(\frac{\mathrm{e}^{\mathrm{T}} U \mathbf{p}_{1}}{\|\mathrm{e}\|\left\|\mathbf{U} \mathbf{p}_{1}\right\|}\right)
$$

この評価関数 $\mathrm{f}$ は $\mathrm{e}$ とその信号部分空間への射影との余 弦であり ${ }^{(8)}$,e が信号部分空間に含まれるとき極值をとる。 そこで, e を構成するパラメー夕を評価関数 $\mathrm{f}$ が大さくな る方向に更新し, $\mathrm{f}$ が 1 となった時べクトル e は信号部分 空間に含まれたことになり，その時のパラメー夕を推定パ ラメータとする。本方法仿信号部分空間への射影を用いる 事で，複数の信号源による信号部分空間を，ある1つの電 流双極子により評価することができ，複数信号源推定の際 に問題となる探索パラメー夕の増加を防ぐことができる。 この操作を 2 次元の場合の代数的表現として,図 1 に示す。

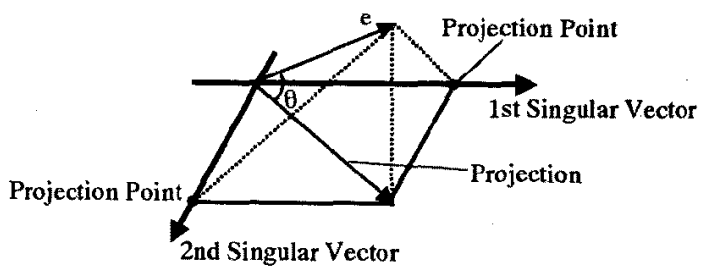

図 1 射影ベクトルとその角度

Fig. 1 The projection vector and the angle

以上の操作を信号源の数分繰り返し，射影係数の行列 $\mathrm{P}=\left(\mathrm{p}_{1}, \mathrm{p}_{2}, \mathrm{p}_{3}, \ldots, \mathrm{p}_{1}\right)$ を決定することで，各列べクトル及び行 ベクトルとして,個々の信号源からの情報として分離され，

$$
\begin{aligned}
& \mathrm{U}_{\mathrm{C}}=\mathrm{UP} \\
& \mathrm{V}_{\mathrm{C}}=\mathrm{P}^{-1} \Omega \mathrm{V}^{\mathrm{T}}
\end{aligned}
$$

を得ることができる。この U $\mathrm{c}$ の各列ベクトルが計測磁界 の測定点情報を表し, $\mathrm{V}_{\mathrm{C}}$ の各行ベクトルが計測磁界の時間 
情報を表す。元の計測磁界は $\mathrm{U}_{\mathrm{C}}$ と $\mathrm{V}_{\mathrm{C}}$ の合成として

$$
\mathrm{B}=\mathrm{U}_{\mathrm{c}} \mathrm{V}_{\mathrm{c}}
$$

で表される。

推定パラメータの探索には，数值微分を用いる必要がな く,その収束の安定性からシンプレックス法(12)を用いた。 以下に信号源推定の流れを示す。

1）計測磁界 Bの特異值分解を行い，特異値の分布より信 号源の数（信号部分空間）を決定する。

2）等磁界分布図，特に接線磁界成分の分布図から信号源 数分の初期值を決定する(極值とする)。

3）ある1つの信号源パラメータの初期值による磁界と信 号部分空間上への射影を評価関数 $\mathrm{f}$ により評価する。

4）シンプレックス法により信号源パラメータを探索し, 評価関数 $\mathrm{f}$ が大くなる方向にパラメー夕を更新する。

5）収束判定基準に達したところでその信号源パラメータ を推定値とする。
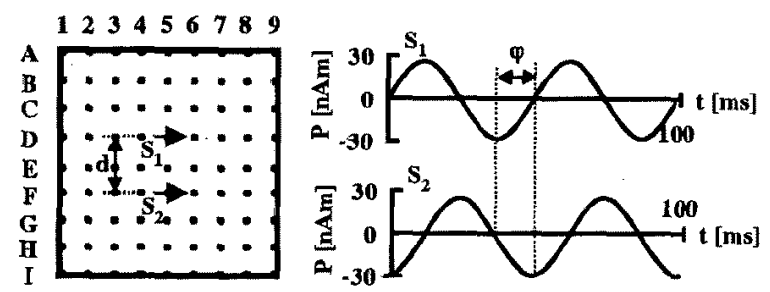

四 2 設定信号源の位置と波形

Fig.2 The location and waveform of established sources

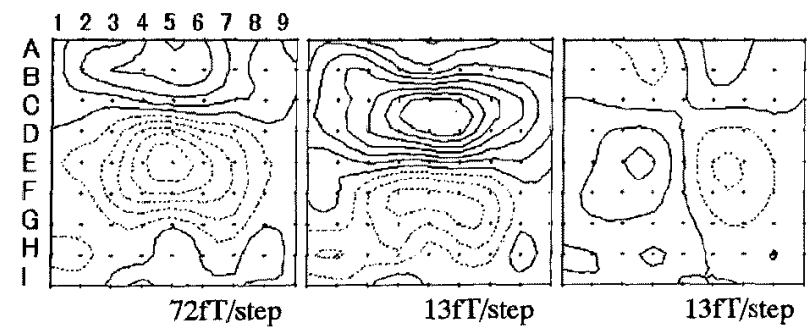

$\begin{array}{lll}\text { (a) } \mathrm{Br} \text { component } & \text { (b) } \mathrm{B} \theta \text { component } & \text { (c) } \mathrm{B} \phi \text { component }\end{array}$

図 3 位相差 90 度における等磁界分布図

Fig.3 Isofield contour maps by two sources oriented in 90 degree phase difference
6）以上の操作(3〜5)を信号源の数分繰り返す。

ここで，初期值の決定は，接線成分が信号源直上で極值 を持ち，信号源の位置の情報を提供する特徵を利用し行う。 しかし, 特異値より決定した信号源の数と接線磁界成分の 極值の数が一致しない時は, 以下の方法により初期值を決 定する。(1)特巽值で求めた信号源の数が極値より少ない場 合汢，大きな値を示した極值から順番に初期值として設定 する。(2)逆に特異值で求めた信号源の数が極值より多い場 合は，複数の信号源が近接し 1 つの極值として合成される ため, 三成分の分布図より 1 つ極值に対してその周辺に 複数の初期值を決定する。この場合, 初期值の位置や遂次 移動法を利用するため, その解は一意的に求まらない。そ こで，初期值を変え絽り返し行い，評伍関数 $\mathrm{f}$ が一番大き な值を示した結果を推定信号源とする。

\section{3. シミュレーション}

$<3.1>2$ つの平行信号源モデル(位相差に対する検 討） 2 つ信号源をモデル内に平行に設定し， $2 \supset$ つ信 号源間の位相差を変化させ信号源推定精度について検討を 行った。信号源は，大脳皮質における感賞野を想定し(1),(13)， モデル表面より深さ $2 \mathrm{~cm}$ の位置に周波数 $20 \mathrm{~Hz}$ で正弦波 状に振動する電流双極子（最大強度 $30 \mathrm{nAm}$ ) とし，2つの 信号源間の距離 d は $4 \mathrm{~cm}$ 固定とした。信号源間の位相差 $\varphi$ を 15 度から 90 度まで 15 度間隔で 6 種類設定し, 得られ た磁界データにランダムノイズを最大強度の 20\%付加し た。本設定信号源（特に位相差 15 度，ノイス $20 \%$ ）は，信 号源間の相関が強く,ノイスが大きい場合であり，MUSIC などの推定法において信号源推定が難しいとされる例であ る。図 2 に設定信号源の様子を示す。ここで，1 例として 位相差 90 度, $10 \mathrm{msec}$ における等磁界分布図を図 3 に示す。 図3において，黒点は測定点を表し，実線は磁界の湧き出 し，破線は磁界の吸い込みを表す。各磁界成分の検出特性 は, 図 2 に示した横向さの信号源（1つの信号源）に対し， 法線磁界成分 $\mathrm{Br}$ は信号源を挟んで双極性の極值を示し， 接線磁界成分 $\mathrm{B} \theta$ 怡信号源の直上で極值を示し，接線磁界成 分 B申恃分布電流の影響に上り信号源の周囲に 4 つの極值 を示す(7)。図 3(a)Br を見ると，1 つの信号源が C5 と D5 の中央付近に横向きに存在する分布と思われ，正しく信号 源を推定するのは困難な例である事がわかる。この時, 図

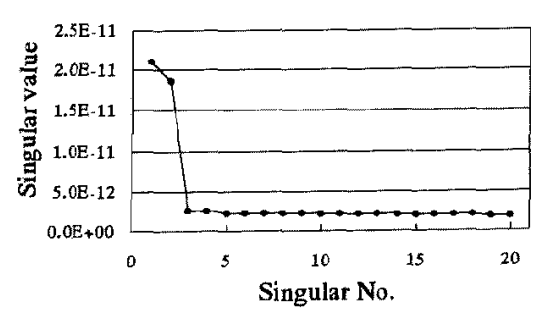

(a) Br component

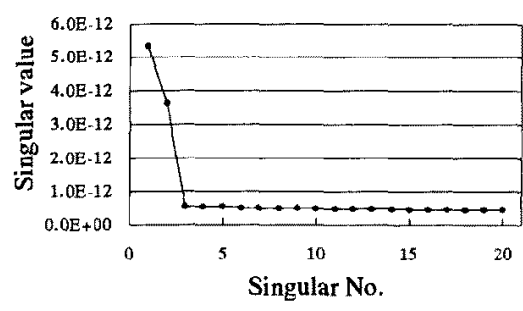

(b) $\mathrm{B} \theta$ component

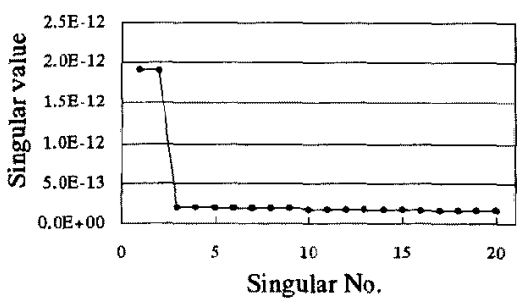

(c) Bф component

図 42 つの信号源の作る磁界の特異值分解結果（位相差 90 度）

Fig.4 Result of singular value decomposition of two sources (90 degree phase difference) 


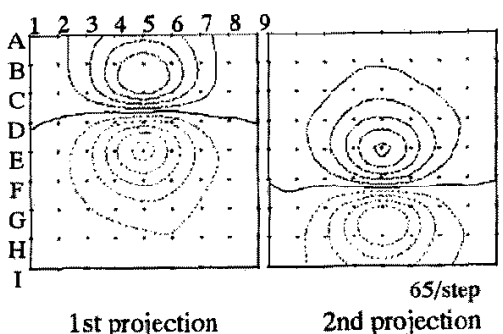

(a) Br component

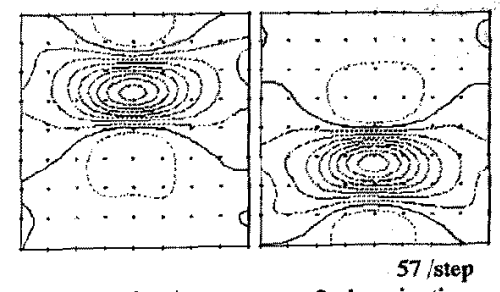

1st projection

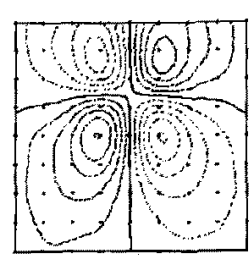

1st projection

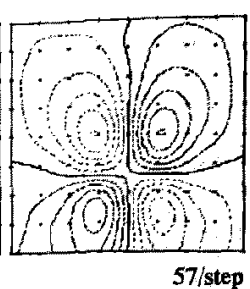

2nd projection

(c) Bф component

(b) B日 component

図 5 特異ベクトル $\mathrm{U}_{\mathrm{C}}$ に対する射影（位相差 90 度）

Fig.5 The projections of singular vector Uc (two sources oriented in 90 degree phase difference)

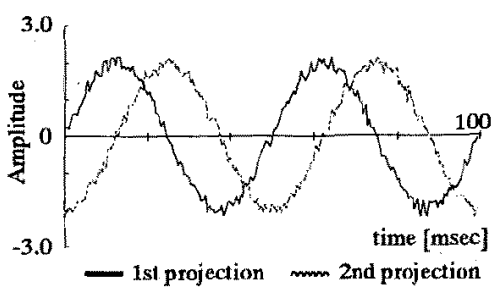

(a) $\mathrm{Br}$ component

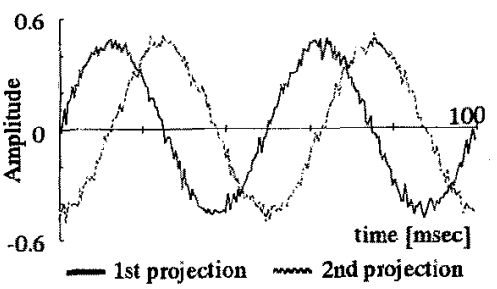

(b) $\mathrm{B} \theta$ component

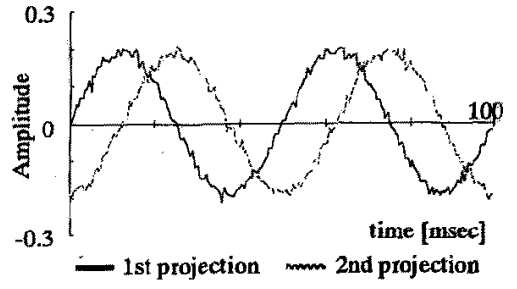

(c) B $\mathbf{\phi}$ component

図 6 特異べクトル $V_{c}$ に対する射影（位相差 90 度）

Fig. 6 The projections of singular vector $V_{c}$ (two sources oriented in 90 degree phase difference)

3(b)B日を見ると，C5とD5 の中央付近に横向き(右向き)に $1 つ, F 5 に$ 横向き(左向き)に 1 つ, 合計 2 つ逆向き信号 源の存在が示唆される。そこで, 図 2 の設定信号源で得ら れる計測磁界の特異值分解を行い,その結果を図 4 に示す。 図 4 を胃ると，磁界の各成分において大きな特異值が $2 つ$ 現れ，第 3 特異值以降はほぼ一定の大ささで第 1 ,第 2 特異 值と比較して 1 桁以上の差がある。この事より信号源の数 は2つと決定できた。そこで，第 1 特異值，第 2 特異值で 表現される信号部分空間に対して信号源推定を行った。信 号源推定により $2 つ の$ 信号源として分離された特翼べクト ルに対する射影を位相差 90 度の時の例として図5,6に示す。 但し，強度は規格化を行い，無次元化している。因 5 は， 式(7)における $U_{C}$ の各列ベクトルが測定点情報に効応する ことから，それぞれの列べクトルを等磁界分布図として表 示してある。四 5(a)Brのそれぞれの分布図は，1 つの横向 きの信号源による磁界分布を表しており，図3(a)Brにおい て 1 つの信号源として見えていたものが，2つの信号源と

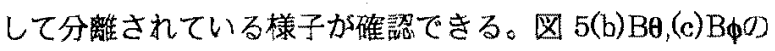
分布も同様に個々の信号源として分離された分布となって いる事が確認できる。図 6 は，式(8)における VCO各行べ クトルが測定時間に刘応することから，それぞれの行べク トルを磁界強度の時間变化として表示してある。各成分と も正弦波状に 90 度の位相差で変動する波形が得られ，設 定信号源の特間変動を的確に分離し表現している事が確認 できる。

図 7 に位相差 $\varphi$ を 15 度から 90 度まで 15 度間隔で 6 種 類設定した時の信号源推定誤差を示す。但し，信婜源推定 の際の初期值は接線磁界成分の極做の位置とし，推定位置
の誤差は，5 個の異なる雑音系列についての平均とした。 図 7 を見ると，信皇源の位相差が小さくなるにつれ推定䛊 差が大きくなっている事が確認でき，この傾向は Br 成分 で最も大きいものとなっている。ノイズを付加しない試行 では位相差による推定誤差は確認されなかった。この事か ら，特異值分解における信号部分空間特定の際の誤差によ る影響と考えられる。しかし，位相差が 15 度となっても 推定誤差は $1 \mathrm{~mm}$ 以内であり，また推定信号源の方向䛊差 は最悪の場合でも 2 度程度となり，位相差による推定誤差 の影㪤は大きな物ではない事が確認できる。

<3.2> 2 つの平行信号源モデル(信号源閏距離に対す る検討） 2 つの信号源(図 2)をモデル内に平行に設定し， 2 つの信号源間の距離を変化させ信号源推定精度について 检討を行った。信号源は，大脳皮質における感党野を想定

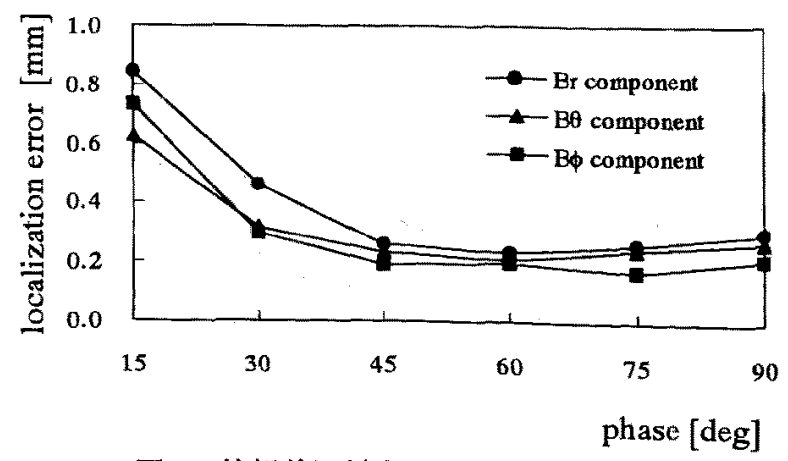

図 7 位相差に対する信号源推定誤差

Fig.7 The estimation error for phase difference of two sources 
し(1),(13)，モデル表面より深さ $2 \mathrm{~cm}$ の位置に周波数 $20 \mathrm{~Hz}$ で正弦波状に振動する電流双極子（最大強度 $30 \mathrm{nAm}$ ) と し，2つの信号源間の位相差 $\varphi$ は 90 度固定とした。信号源 間距離 $\mathrm{d}$ は $1 \mathrm{~cm}$ から $6 \mathrm{~cm}$ まで $1 \mathrm{~cm}$ 刻みで 6 種類設定し， 得られた磁界データにランダムノイズを最大強度の $20 \%$ 付加した。

ここで，1例として信号源距離 $2 \mathrm{~cm}, 19 \mathrm{msec}$ における等 磁界分布図を図 8 に示す。図 8 を見ると，1 万0信号源か E5 の位置に横向きに存在する分布と思われ，信号源を推 定するのは困難な例である事がわかる。

そこで，この設定信号源で得られる計測磁界を特異值分 解した結果，図 4 と同様に磁界の各成分，どの位相差にお いても大きな特異値が 2 つ現れ，第 3 特異值以降はほぼ定の大きさで第 1 ,第 2 特異值と比較して 1 桁以上の差が

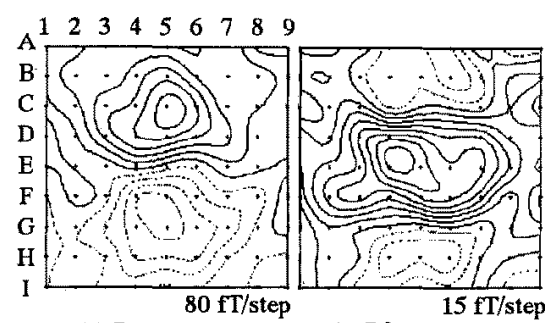

(a) Br component (b) $\mathrm{B} \theta$ component

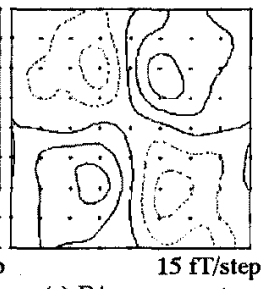

(c) B $\phi$ component
図 8 信号源距離 $2 \mathrm{~cm}$ における等磁界分布図

Fig.8 Isofield contour maps by two sources oriented in $2 \mathrm{~cm}$ apart
あった。この事より信号源の数は 2 つと決定できた。した がって，第 1 特異值，第 2 特異值で表現される信号部分空 間に対して信号源推定を行った。信号源推定により $2 つ の$ 信号源として分離された特巽ベクトルに対する射影を信号 源距離 $2 \mathrm{~cm}$ の時の例として図 9,10 に示す。<3.1>と同 様に，図 9 は測定点情報に対応することから，それそれの 列ベクトルを等磁界分布図として表示してある。図 $9(\mathrm{a}) \mathrm{Br}$ のそれそれの分布図は1つの横向きの信号源による磁界分 布を表しており,図 8(a)Brにおいて1つの信号源として見 えていたものが，2つの信号源として分離されている様子 が確認できる。図 9(b)B 源として分離された分布となっている事が確認できる。ま たく3.1>と同様に，図 10 は測定時間に対応することから， それそれの行べクトルを磁界強度の時間変化として表示し てある。各成分とも正弦波状に 90 度の位相差で変動する 波形が得られ，設定信号源の時間変動を的確に分離し表現 している事が確諗できる。

図 11 に信号源間距離 $\mathrm{d}$ を $1 \mathrm{~cm}$ から $6 \mathrm{~cm}$ まで $1 \mathrm{~cm}$ 刻み で 6 種類設定した時の推定䛊差を示す。図 11 を見ると， 信号源間距離が $1 \mathrm{~cm} 0$ 時, 推定䛊差は極端に悪くなって いる。この時の 2 つの推定信号源は，ほほ同一の位置に推 定され，その位置は 2 つの信号源の中間点付近であった。 この事から，平行する $2 \supset の$ 信号源閒の距離が $2 \mathrm{~cm}$ 以下 の場合，個々の信号源の分離ができず，推定誤差が生じる 事がわかる。しかし，信号源間の距離が $2 \mathrm{~cm}$ 以上の場合

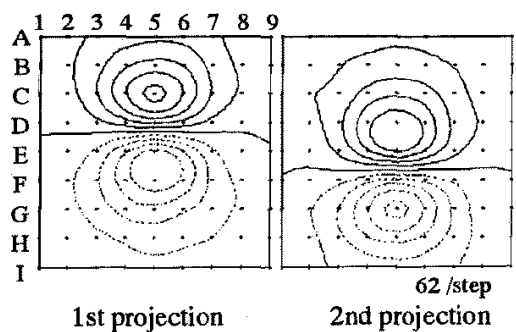

(a) $\mathrm{Br}$ component

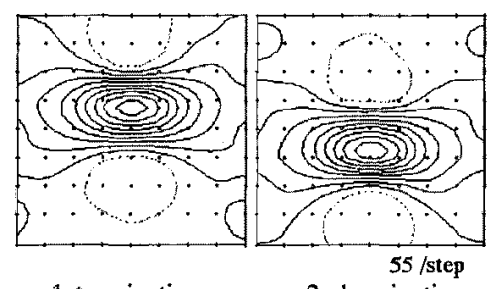

1st projection

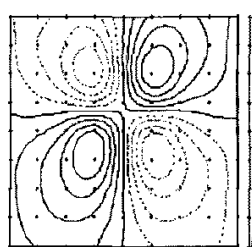

1st projection

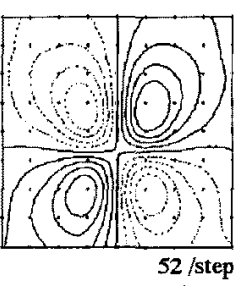

2nd projection

図9特異ベクトル $\mathrm{U}_{\mathrm{C}}$ に対する射影（信号源距離 $2 \mathrm{~cm}$ ）

Fig.9 The projections of singular vector $U_{c}$ (two sources oriented in $2 \mathrm{~cm}$ apart)

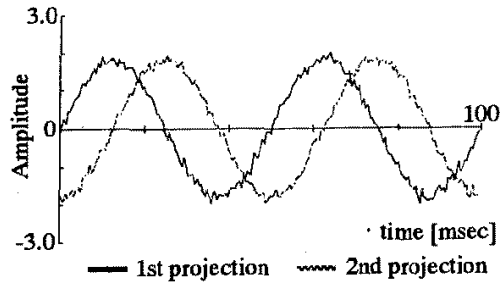

(a) Br component

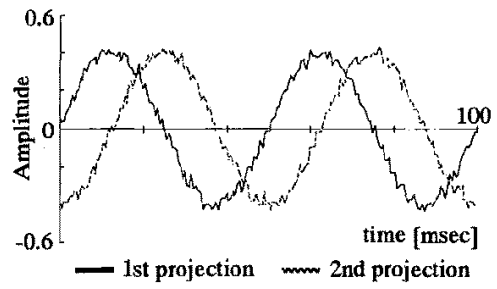

(b) $\mathbf{B} \boldsymbol{\theta}$ component

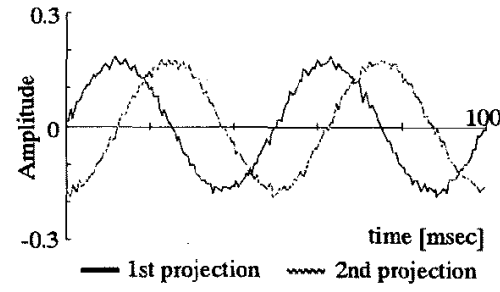

(c) $\mathrm{B} \phi$ component

困 10 特異ベクトル $\mathrm{V}_{\mathrm{C}}$ に対する射影（信号源距離 $2 \mathrm{~cm}$ )

Fig.10 The projections of singular vector $\mathrm{Vc}$ (two sources oriented in $2 \mathrm{~cm}$ apart) 
推定は可能となり，大脳皮質の溝の間隔を考えると妥当な 性能を有すると考えられる。

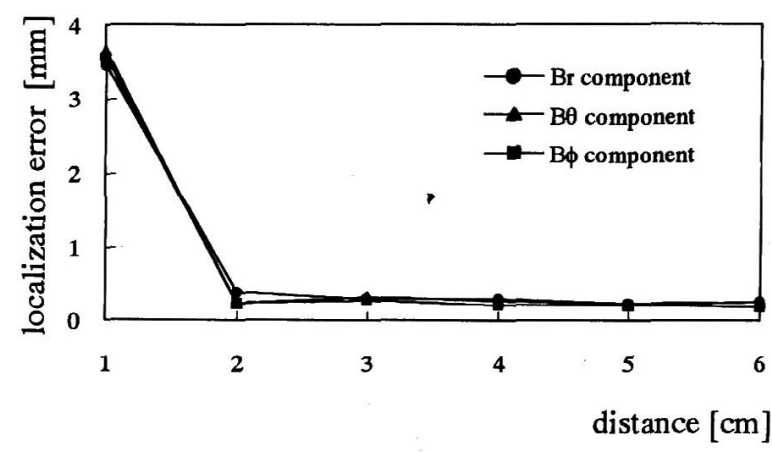

図 11 信号源間距離と推定誤差

Fig.11 The estimation error for distance of two sources

\section{4. まとめ}

複数信号源による磁界を個々の信号源として推定する信 号源推定法を提案した。本方法は, 計測磁界デー夕の時空 間情報を利用する事により得られる信号部分空間に対する パターンマッチングとしてなされる。これにより，複数信 号源推定の際問題となる信号源の数の決定や推定パラメー 夕の增加を抑える事ができ，推定が行えた。また，従来難 しいとされていた, 近接した信号源, 独立性（直交性）の 弱い信号源に対しても良好な推定結果を得る事ができ，脳 磁界信号源推定に有効であると考えられる。

本研究の一部は, ハイテクリサーチセンター研究助成,

平成 11 年度科学研究費補助金 基盤研究 (C), 東京電機 大学総合研究所助成の元で行った。

最後に本研究を進めるにあたり，協力してくれた東京電 機大学大学院生（現オムロン株式会社）小林直嗣君に感謝 します。

（平成 11 年 11 月 2 日受付,平成 12 年 5 月 26 日再受付）

\section{文献}

（1）内川義則，小谷誠 :「等価電流双極子法による体性感 覚誘発脳磁界の信号源追跡」, 電気学会論文誌, 112-A 2,127 (1992)

(2) S.Ueno, K.Iramina : "Modeling and Source Localization of MEG Activities", Brain Topography, 3, 151 (1990)

(3) O. Oshiro, M. Mukai, F. Takeuchi, S. Kuriki : "Analysis of errors in neuromagnetic localization of multiple current dipole sources", Phys.Med.Biol., 37,845 (1992)

（4）斎藤兆古：「電磁界系逆問題解析技術の進歩」，電気 学会誌 A, Vol.114-A, No.6, 432 (1994)

(5) J.C.Mosher, P.S.Lewis, R.M.Leahy : "Multiple Dipole Modeling and Localization from
Spatio-Temporal MEG Data", IEEE Trans. Biomed. Eng., BME-39, 541 (1992)

（6）工藤博幸，前村貴志，斎藤恒雄 : 「信号部分空間法に よる時空間生体磁気テータからの信号源推定」, 電子 情報通信学会論文誌，D-II，Vol.178-D-II, No.3, 559 (1995)

（7）小林宏一郎，内川義則：「三次元磁界計測に基づく制 約条件を用いた複数信号源推定」, 電気学会誌 $\mathrm{A}$, Vol.118-A, No.3, 274 (1998)

（8）早乙女英夫, 滳田和泰, 早野誠治, 斎藤兆古：

「Sampled Pattern Matching 法による生体内電流 分布推定」, 電気学会誌 C, Vol.113, No.1, 69 (1993)

（9）小林宏一郎：「三次元磁界計測による探索法を用いた 複数信号源推定」, 電気学会誌 A, Vol.118-A, No.11, 1271 (1998)

（10）遅澤悟，小林護，石山敦士，葛西直子：「譄磁界計測に おける体積電流の影響一半球ファントムモデルによ る実験と解析一」, 電気学会論文誌 C, Vol.116-C, No.2, 210 (1996)

(11) D.Geselowitz : "On the Magnetic Field Generated Outside an Inhomogeneous Volume Conductor by Internal Current Sources", IEEE Trans. Magn., MAG-6, 346 (1970)

(12) 佐藤郁郎: 最小二乗法その理論と実際, p.126, 山海堂 (1997)

(13) S. Kuriki, T. Nogai, Y. Hirata : "Cortical sources of middle latency responses of auditory evoked magnetic field", Hear Res., 92, 45 (1995)

小林 宏一郎 （正員） 1968 年生まれ。94 年 3 月東京

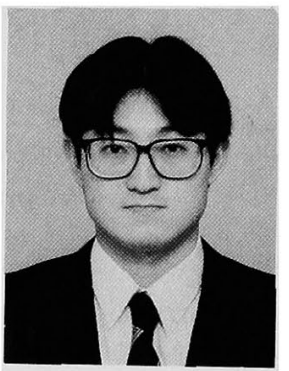
電機大学大学院理工学研究科応用 電子工学専攻修士課程修了。同年 4 月池上通信機（株）入社。95 年 東京電機大学理工学部応用電子工 学科助手。生体磁気計測及び信号 処理に関する研究に従事。日本M $\mathrm{E}$ 学会, 日本応用磁気学会, 日本 生体磁気学会会員。博士 (工学)

内川军則 （正員） 1949 年生まれ。79 年 3 月東京

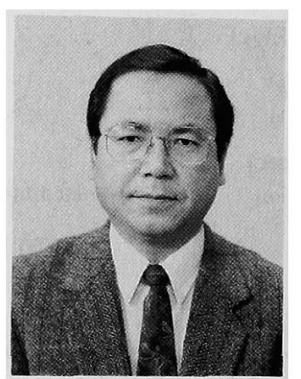
電機大学大学院工学研究科博士課 程修了。同年 4 月同大学工学部助 手, 81 年東京大学工学部助手, 83 〜85 年旧西ドイツ国立物理工学 研究所研究員, 88 年東京電機大学 理工学部助教授, 93 年同教授。微 小生体信号の計測と信号処理に関 する研究に従事。IEEE，日本M $\mathrm{E}$ 学会評議員, 日本応用磁気学会, 日本生体磁気学会理事, 電子情報通信学会会員。工学博士。 